\title{
6. The approaches of the EU Court of Justice and the European Court of Human Rights vis-à-vis discrimination on the ground of nationality in social security Frans Pennings*
}

\section{INTRODUCTION}

The negotiations on the accession of the European Union to the European Convention on Human Rights (henceforth: ECHR or Convention) raise several complicated questions of a formal nature, e.g. on the relation between Member State(s) and the Union in a particular procedure before the European Court of Human Rights (Court of Human Rights) and on the coordination of the interpretation of EU law by the EU Court of Justice and the Court of Human Rights. ${ }^{1}$ Considerable progress was made in this area, ${ }^{2}$ but in December 2014 the Court of Justice delivered its opinion on the accession of the EU to the ECHR, and this raised important questions. ${ }^{3}$ These issues will not be addressed here, because they are outside the scope of this volume.

Instead, I will focus on a material issue, i.e. a comparison of the approaches of both Courts in discrimination cases. This may become important when the EU finally accedes to the ECHR. It is, however, also important now, for academic purposes alone, since it shows alternative approaches and raises the need for explaining differences between the approaches.

Currently an instrument of EU law can already be the subject of cases before the Court of Human Rights in so far as a Member State has implemented this instrument. However, after the accession of the EU to the ECHR, EU law itself can be the subject

* This text was previously published in the Utrecht Law Review: Frans Pennings, 'NonDiscrimination on the Ground of Nationality in Social Security: What are the Consequences of the Accession of the EU to the ECHR?' (2013) 9(1) Utrecht Law Review. The editors considered it useful to include a slightly adapted version of this article to supplement the analysis of ECHR case law by Koch (Chapter 5 of this volume). The article is published here with the permission of $U L R$.

1 See for a recent draft text of the accession agreement, CDDH-UE(2011)10 on the website of the Council of Europe, www.coe.int/t/dghl/standardsetting/hrpolicy/accession/Meeting reports/CDDH-UE_2011_10_RAP_en.pdf (last visited 7 December 2012).

2 See, for instance, T Lock, 'Walking on a Tightrope: The Draft ECHR Accession Agreement and the Autonomy of the EU Legal Order' [2011] CMLR $1026 \mathrm{ff}$; see also JP Jacqué, 'The Accession of the European Union to the European Convention on Human Rights and Fundamental Freedoms' (2011) CMLR 995 ff.

3 Opinion 2/13, not yet reported, ECLI:EU:C:2014:2454. 


\section{Research handbook on European social security law}

of procedures before the Court of Human Rights. ${ }^{4}$ This means that EU rules and practice must satisfy the provisions of the Convention. For our purpose it is therefore relevant to investigate the areas where EU law allows discrimination on the ground of nationality while the ECHR does not. In exactly this area it can be expected that the accession of the EU to the Convention may have certain effects. This approach thus requires a comparison of EU law and the Convention, including the case law concerning discrimination on the ground of nationality.

I will discuss which effects follow from the EU's accession to the Convention for a particular fundamental right, i.e., non-discrimination on the ground of nationality in the area of social advantages. The comparison is therefore not a complete one of all cases of discrimination on the ground of nationality, but focuses on those areas where differences can be expected. Thus the central question of this contribution is whether cases of discrimination on the ground of nationality which are allowed under EU law are problematic for the Convention.

Discrimination on the ground of nationality is of special interest, since the EU makes use of the nationality condition in order to define the scope and the contents of several of its instruments, in particular also in relation to social advantages. The application of this condition may be different from that under the Convention and therefore it is worthwhile studying this issue.

Both EU primary and secondary instruments and the ECHR have non-discrimination clauses, but these may have different scopes and interpretations. Moreover, there is a difference from other fundamental rights, which 'double up' in the Treaty and the Convention, such as the prohibition of discrimination on the ground of gender. Therefore the prohibition of discrimination on the ground of nationality deserves special attention. Of course, this prohibition is also relevant in areas other than social advantages, ${ }^{5}$ but the topic is of special interest since exactly this area is of a highly politically sensitive nature, because states wish to remain exclusively competent with regard to the organisation of their welfare systems.

It is furthermore useful to keep in mind that the non-discrimination provisions within the EU context differ in several aspects from that in the ECHR context. Within the EU, non-discrimination on the basis of nationality is closely related to the free movement of EU citizens. For these citizens the non-discrimination rule is a fundamental right vis-à-vis another Member State. Secondly, EU law itself distinguishes between EU citizens and non-EU citizens (third-country nationals), although currently some (specific) non-discrimination provisions apply to third-country nationals as well. In the ECHR context the non-discrimination clause is not related to a particular purpose and does not distinguish between categories of citizens.

4 For a more precise description of the liability of Member States under the current law, see also Leonard Besselink, 'The EU and the European Convention of Human Rights after Lisbon: From "Bosphorus" Sovereign Immunity to Full Scrutiny?', SSRN, http://ssrn.com/abstract $=1132788$ or http://dx.doi.org/10.2139/ssrn.1132788 (last visited 28 April 2015).

5 The term 'social advantages' is chosen since our topic is not limited to social insurance or social security, but includes all benefits on the basis of whatever instrument or financing method. 
Within the ECHR context the prohibition of discrimination on the ground of nationality is - as a fundamental right - a more general concept, and a justification is needed for distinctions between different nationalities to be allowed.

Since the EU instruments can be brought before the European Court of Human Rights after accession, it is interesting to see whether the two different approaches can be reconciled.

In the following sections I will first discuss the case law of the Court of Human Rights (Section II); then I will address the EU provisions and case law (Section III); in Section IV, I will analyse the differences and Section V will provide some conclusions.

\section{THE CASE LAW OF THE EUROPEAN COURT OF HUMAN RIGHTS}

\section{II.i Introduction: The Applicability of Article 14 to Social Advantages}

Article 14 ECHR provides that the enjoyment of rights and freedoms set forth in this Convention shall be secured without discrimination on any ground such as sex, race, colour, language, religion, political or other opinion, national or social origin, association with a national minority, property, birth or other status. Thus nationality is a forbidden ground for making a distinction.

Article 14 is not a free-standing provision, but it complements the other substantive provisions of the Convention and the Protocols. Thus it has effect solely in relation to 'the enjoyment of the rights and freedoms' safeguarded by these provisions. Consequently, this provision cannot be applied in any case of alleged discrimination. ${ }^{6}$ The Court has consistently held this approach in its case law, e.g. in the Gaygusuz judgment. ${ }^{7}$ However, the discrimination provision can be applied in social security cases since in the Gaygusuz judgment the Court also ruled that a benefit can be within the ambit of Article 1 of the First Protocol, i.e. the protection of property, and thus within the scope of the Convention. ${ }^{8}$ Article 1 reads:

Every natural or legal person is entitled to the peaceful enjoyment of his possessions. No one shall be deprived of his possessions except in the public interest and subject to the conditions provided for by law and by the general principles of international law.

The preceding provisions shall not, however, in any way impair the right of a state to enforce such laws as it deems necessary to control the use of property in accordance with the general interest or to secure the payment of taxes or other contributions or penalties.

6 Protocol 12 has introduced a more general equality clause. However, few countries have so far ratified it, and it is not a Protocol which is part of the EU accession agreement.

7 Gaygusuz v Austria, 1996-IV 1129. On this judgment, see also S van den Bogaerd (ed), Social Security, Non-discrimination and Property (Maklu 1997); H Verschueren, 'EC Social Security Coordination Excluding Third-Country Nationals: Still in Line with Fundamental Rights after the Gaygusuz Judgement' [1997] CMLR 1991; F Pennings, 'The Potential Consequences of the Gaygusuz Judgment' [1999] EJSS 181.

8 The First Protocol is part of the accession agreement. 


\section{Research handbook on European social security law}

The Gaygusuz case concerned the refusal of so-called emergency assistance, a kind of Austrian social assistance, to Mr Gaygusuz, on the ground that he did not have Austrian nationality; instead, he had Turkish nationality.

In this judgment the Court required, for the protection of property to be acceptable, that a link could be established between the financing method and the benefit concerned, more specifically that contributions had been paid. In this case the link between the contributions paid and the emergency assistance was an indirect one, but it was considered to be sufficient by the Court. The indirect link was created by the fact that the emergency assistance was payable only after the right to (contributory) unemployment benefit had expired. Therefore, in the Court's view, the emergency benefit was linked to the payment of contributions to the unemployment insurance fund and, as a result, this benefit was within the ambit of the Protocol and, consequently, Article 14 was applicable to this case.

In later cases the Court abandoned the requirement of a link between a benefit and contributions as an accession requirement for Article 14. A landmark decision was the Stec judgment, ${ }^{9}$ which concerned an issue of discrimination on the ground of gender, but is also relevant to our topic, since its major relevance lay in the Court's new view on the scope of the protection of property. In this judgment, the Grand Chamber accepted that the Gaygusuz judgment had caused confusion relating to the criteria which are applicable for income protection and that it was necessary to "examine afresh' the question whether a claim to a non-contributory welfare benefit should attract the protection of Article 1 of the First Protocol. For this purpose the Court acknowledged that there exists a wide range of social security benefits designed to confer entitlements which arise as of right. Given the variety of funding methods, and the interlocking nature of benefits under most welfare systems, the Court considered that it appears increasingly artificial to hold that only benefits financed by contributions to a specific fund fall within the scope of Article 1 of the First Protocol. In the modern, democratic state, many individuals are, for all or part of their lives, completely dependent for survival on social security and welfare benefits. Many domestic legal systems recognise that such individuals require a degree of certainty and security, and provide for benefits to be paid - subject to the fulfilment of the conditions of eligibility - as of right. Where an individual has an assertable right under domestic law to a welfare benefit, the importance of that interest should also be reflected by holding Article 1 of the First Protocol to be applicable.

So this is the new criterion: is there an assertable right to a welfare benefit? If the answer is in the affirmative, Article 14 (the non-discrimination rule) can be applied. However, Article 1 of the First Protocol is not only an admissibility provision, but also has a material content, i.e. the protection of property. I will address this latter dimension in Section II.iii, since some of the issues relating to (indirect) discrimination on the ground of nationality can also be covered by the property protection rules.

Below I will discuss the interpretation of Article 14 and the interpretation of the right to property.

9 Stec v UK App nos 65731/01 and 65900/01 (ECHR, 12 April 2006). 


\section{II.ii Article 14 ECHR}

\section{II.ii.a Direct discrimination on the ground of nationality}

In the already-mentioned Stec judgment, the Court considered that Article 14 does not prohibit a Member State from treating groups differently in order to correct 'factual inequalities' between them; indeed, in certain circumstances a failure to attempt to correct inequality through different treatment may in itself give rise to a breach of the article.

Then the Court continued, and used the argument already introduced in the Gaygusuz judgment and later judgments, that a difference in treatment is discriminatory, for the purposes of Article 14, if it has no objective and reasonable justification, that is if it does not pursue a legitimate aim or if there is not a reasonable relationship of proportionality between the means employed and the aim sought to be realised.

It added that Contracting States enjoy a certain margin of appreciation in assessing whether and to what extent differences in otherwise similar situations justify different treatment. The scope of this margin will vary according to the circumstances, the subject-matter and the background. ${ }^{10}$ A wide margin is usually allowed to the state under the Convention when it comes to general measures of economic or social strategy. Because of their direct knowledge of their society and its needs, the national authorities are in principle better placed than the international Court to appreciate what is in the public interest on social or economic grounds, and the Court will generally respect the legislature's policy choice unless it is 'manifestly without reasonable foundation'.

However, and now the Court comes to an important criterion: very weighty reasons would have to be put forward before the Court could regard a difference in treatment based exclusively on the ground of nationality as compatible with the Convention.

In the Gaygusuz case the Austrian government had submitted that the statutory provision in question was not discriminatory. It argued that the difference in treatment was based on the idea that the state has special responsibility for its own nationals and must take care of them and provide for their essential needs. Moreover, the Unemployment Insurance Act laid down certain exceptions to the nationality condition. Lastly, at the material time, Austria was not bound by any contractual obligation to grant emergency assistance to Turkish nationals.

The Court did not find this argument to be persuasive, now that Mr Gaygusuz was legally resident in Austria and worked there at certain times, paying contributions to the unemployment insurance fund in the same capacity and on the same basis as Austrian nationals. The authorities' refusal to grant him emergency assistance was based exclusively on the fact that he did not have Austrian nationality. Apart from this he was in a like situation to Austrian nationals as regards his entitlement to the emergency benefit. The difference in treatment between Austrians and non-Austrians as regards an entitlement to emergency assistance was thus not based on any 'objective and reasonable justification'.

10 See for example Petrovic v Austria 1998-II, § 38, where the authorities' refusal to grant parental leave allowance to a father, on the ground that the allowance was only available to mothers, was not found to have exceeded the margin of appreciation allowed to them. 


\section{Research handbook on European social security law}

Another judgment which is relevant to the non-discrimination rule is that of Koua Poirrez $v$ France. ${ }^{11}$ It concerned a person with Ivory Coast nationality who had been physically disabled since the age of seven and had been adopted by a French national. He was assessed as being 80 per cent disabled. In May 1990 he applied for an allowance for disabled adults. His application was refused on the ground that he was neither a French national nor a national of a country which had entered into a reciprocity agreement with France.

It is interesting that the case was first brought before the Court of Justice. In a judgment of 16 December 1992 this Court issued a ruling that the refusal to award the benefit to the applicant was not incompatible with the relevant articles of the EEC Treaty. It pointed out that the applicant's adoptive father could not claim to be a 'migrant worker', which was the category to which the European provisions in question applied, since the applicant's adoptive father, being French, had always lived and worked in France. ${ }^{12}$ In doing so, the Court did not examine the question whether the refusal to award the applicant the allowance was, in general, compatible with Community law or not.

In 1998, according to a new Act, the nationality condition was lifted for awards of non-contributory allowances. After several procedures Poirrez was awarded benefit as from June 1998. Now his claim for the preceding period led to a procedure before the Court of Human Rights and a judgment. Before the Court, the government had submitted that the distinction made, prior to the 1998 Act, between nationals and foreigners when awarding the allowance for disabled adults pursued a legitimate aim, which was a balance between the state's welfare income and expenditure. The requirement of proportionality had also been satisfied since foreign nationals had not been deprived of all resources since they were entitled to, among other things, the minimum welfare benefit.

The Court repeated its formula that very weighty reasons would have to be put forward before the Court could regard a difference in treatment based exclusively on the ground of nationality as compatible with the Convention. In this case the domestic authorities' refusal to award him the allowance in question was based exclusively on the fact that he did not have the requisite nationality. The Court found the arguments advanced by the respondent government unpersuasive. The difference in treatment regarding entitlement to social benefits between French nationals or nationals of a country having signed a reciprocity agreement and other foreign nationals was not based on any 'objective and reasonable justification'.

Finally, also in the Luczak $v$ Poland judgment the Court accepted that the direct discrimination which existed in this case was inconsistent with Article $14 .{ }^{13}$ The applicant, who was a French national of Polish origin, had moved to Poland in about 1984. After years of employment, he started a farm, but was excluded from the social security scheme for farmers since he did not have Polish nationality.

The government pointed out that the distinction at issue pursued the legitimate aim of protecting a vulnerable group by allowing its members to have access to and benefit

11 Koua Poirrez v France App no 40892/98 (ECHR, 30 September 2003).

12 Case C-206/91 [1992] ECR 6685.

13 Luczak v Poland App No 77782/01 (ECHR, 27 November 2007). 
from the scheme subject to the payment of a modest contribution and the condition of having Polish nationality prior to 2004 and had played a vital role in directing state support to those in particular need. The farmers' scheme was 95 per cent financed from the budget and constituted a heavy burden on taxpayers and the economy alike.

The Court attached importance to the fact that the applicant was permanently resident in Poland, had previously been affiliated to the general social security scheme and had contributed as a taxpayer to the funding of the farmers' scheme. It reiterated that very weighty reasons would have to be put forward by the respondent government in order to justify a difference in treatment based, as in the present case, exclusively on the ground of nationality. The creation of a particular social security scheme for farmers that is heavily subsidised from the public purse could be regarded as pursuing an economic or social strategy falling within the state's margin of appreciation, but legislation regulating access to such a scheme must be compatible with Article 14 of the Convention. Where it is shown that there are reasonable and objective grounds for excluding an individual from the scheme, the principle of proportionality will then come into play. In particular, even where weighty reasons have been advanced for excluding an individual from the scheme, such exclusion must not leave him in a situation in which he is denied any social insurance cover, whether under a general or a specific scheme, thus posing a threat to his livelihood. Indeed, to leave an employed or self-employed person bereft of any social security cover would be incompatible with current trends in social security legislation in Europe. The Court also noted that the government argued that the difference in treatment at issue was justified by the social and economic policies pursued prior to 2004, when Poland was obliged to change the relevant law following its accession to the European Union. The government had not however explained, the Court remarked, why its public policy goals in respect of the farmers' scheme suddenly lost their relevance after 2004. The Court concluded by saying that the government had not provided any convincing explanation of how the general interest was served by refusing the applicant's admission to the farmers' scheme during the period in question.

It has been argued that the Moustaquim case ${ }^{14}$ could be an argument that the Court of Human Rights will not consider preferential treatment for EU nationals to be contrary to the Convention. This case concerned a Moroccan man who had been deported from Belgium, who then stayed for a couple of years in Sweden, and who wished to have the deportation order revoked. In this case the Court ruled that there is an objective and reasonable justification for the refusal as Belgium belongs, together with those states, to a special legal order. In this case the right to enter and stay in the country was at stake, which is very different from the area of social security, since it is generally accepted that the right to equal treatment does not concern the right to enter a particular country. ${ }^{15}$ As far as social security is concerned, the issue of equal treatment only arises after a person has the right to stay legally in a country. Or, in other words, differences on ground of nationality can still be allowed in conditions for

\footnotetext{
14 Moustaquim App no 12313/86 (ECHR, 18 February 1991).

15 Relevant also is that Protocol 4 to the Convention itself makes a difference as far as nationality is concerned, since persons having the nationality of a country cannot be expelled from that country.
} 


\section{Research handbook on European social security law}

access to the country, but claiming social advantages is a second stage, where there have to be very weighty reason for unequal treatment. Therefore, from this judgment we cannot derive that a difference between third-country nationals and EU nationals is generally allowed, although it is certainly not impossible that the EU context may be, in particular circumstances, a justification for making distinctions, provided they constitute very weighty reasons.

Conclusion. The Court decided that very weighty reasons would have to be put forward before the Court could regard a difference in treatment based exclusively on the ground of nationality (i.e. direct discrimination) as being compatible with the Convention. Even if EU law does not require Member States to treat third-country nationals equally with nationals, this may be required on the basis of the Convention (Gaygusuz, Poirrez). And even if EU law can explain why persons are excluded, or have to be included, that is not decisive (Luczak). Despite the room for states to have margins of appreciation to have a particular policy or scheme, for limiting access to the scheme on the ground of nationality the criterion of very weighty reasons applies.

\section{II.ii.b Indirect discrimination}

In its case law, the Court of Human Rights has not (yet) developed a concept of indirect discrimination, a concept which is so well known from the Court of Justice's case law and which is now also laid down in EU instruments. For instance, in terms of the Directive on the implementation of the principle of equal opportunities and equal treatment of men and women in matters of employment and occupation, ${ }^{16}$ indirect discrimination shall be taken to occur where an apparently neutral provision, criterion or practice disadvantages a substantially higher proportion of the members of the other sex, unless that provision, criterion or practice is objectively justified by a legitimate aim and the means of achieving that aim are appropriate and necessary (Article 2(1)(b)). An obvious example of indirect discrimination on the ground of nationality is a residence condition, e.g. for receiving a benefit, since this will normally affect foreigners more than nationals, and it will be more often the case that foreigners do not live in the state where they work. So this is the approach within EU law.

The $L B v$ Austria judgment of the Court of Human Rights shows that this Court is not so sensitive to rules with discriminatory effects which are not directly discriminatory. The case was that of an Austrian national of Hungarian origin who complained that the Austrian authorities had refused to allow him to pay contributions for the time that he had been in school and studied in Hungary. The Court did not accept that the difference in treatment was based on national origin. It considered that the legislation in question did not distinguish on the basis of nationality and found that making participation in an insurance scheme dependent on employment in a specific country was not unreasonable or arbitrary. ${ }^{17}$

If a distinction is made that does not constitute direct discrimination on the ground of nationality or one of the other mentioned grounds, this can also be assessed on a

16 Directive 2006/54/EC of the European Parliament and of the Council of 5 July 2006, [2006] OJ L 204, 23.

17 LB v Austria App no 39802/98 (ECHR, 18 April 2002).

Columns Design XML Ltd / Job: Pennings-Research_handbook_European_social_security_law / Division: 07_Chapter6 /Pg. Position: 8 | Date: 
ground other than nationality, since Article 14 not only mentions specific forbidden grounds, but also prohibits discrimination due to 'other status'. ${ }^{18}$

A recent case where this clause was applied to a situation where residence conditions were disputed is the Carson case. ${ }^{19}$ The case concerned 13 pensioners who had often spent long periods of their working life in the UK (during which they had paid social security contributions), before emigrating to another country (outside the EU), i.e. South Africa and Canada. After having become entitled to their pension, the pension was no longer upgraded if they left the UK, and therefore it became considerably lower than if it had benefited from upgrading. The Act required the upgrading to maintain its value 'in relation to the general level of prices obtaining in Great Britain'. For non-residents there was no such upgrading, unless they lived in a country with a bilateral reciprocal social security agreement with the UK.

The Court considered that it had established in its case law that only differences in treatment based on an identifiable characteristic, or 'status', are capable of amounting to discrimination within the meaning of Article $14,{ }^{20}$ and there must be a difference in the treatment of persons in analogous, or relevantly similar, situations. ${ }^{21}$ Such a difference in treatment is discriminatory if it has no objective and reasonable justification; in other words, if it does not pursue a legitimate aim or if there is not a reasonable relationship of proportionality between the means employed and the aim sought to be realised. The Contracting State enjoys a margin of appreciation in assessing whether and to what extent differences in otherwise similar situations justify different treatment. A wide margin is usually allowed to the state under the Convention when it comes to general measures of economic or social strategy.

The Court was not concerned, it continued, with an assessment of the effects, if any, on the many thousands in the same position as the applicants, but its role is to determine the question of principle, namely whether the legislation as such unlawfully discriminates between persons who are in an analogous situation.

The Court then had to decide whether a distinction on the ground of residence could fall under the ground 'or any other status'. The words 'other status' have a wide meaning so as to include, in certain circumstances, a distinction which is made on the basis of the place of residence. The second question was whether the applicants were in a relevantly similar position to pensioners receiving up-rating. As the Court has established in its case law, in order for an issue to arise under Article 14, the first condition is that there must be a difference in the treatment of persons in relevantly similar situations. The applicants' principal argument in support of their claim to be in a relevantly similar situation to pensioners who receive up-rating was that they had also worked in the United Kingdom and had paid compulsory contributions to the National

\footnotetext{
18 M Cousins, The European Convention on Human Rights and Social Security Law (Intersentia 2008) 67.

19 Carson v United Kingdom (2009) 48 EHRR 41. See also M Cousins, 'The European Convention on Human Rights, Non-Discrimination and Social Security: Great Scope, Little Depth?' (2009) 16 Journal of Social Security Law 118 ff.

${ }_{20}$ Kjeldsen, Busk Madsen and Pedersen App nos 5095/71 and 5920/71 (ECHR, 7 December 1976).

21 DH and Others $v$ the Czech Republic App no 57325/00( ECHR, 7 February 2007); Burden $v$ the United Kingdom App no 57325/00 (ECHR, 13 November 2007).
} 


\section{Research handbook on European social security law}

Insurance Fund. The Court considered, however, that unlike private pension schemes, where contributions are paid into a specific fund and where those contributions are directly linked to the expected benefit returns, National Insurance contributions have no exclusive link to retirement pensions. It is impossible to isolate the payment of National Insurance contributions as a sufficient ground for equating the position of pensioners who receive up-rating and those, like the applicants, who do not. The payment of National Insurance contributions alone was insufficient to place the applicants in a relevantly similar position to all other pensioners, regardless of their country of residence. Given that the pension system is primarily designed to serve the needs of those who are resident in the United Kingdom, it was difficult to draw any genuine comparison with the position of pensioners living elsewhere, because of the range of economic and social variables which apply from country to country. Neither did the Court consider that the applicants were in a relevantly similar position to pensioners living in countries with which the United Kingdom has concluded a bilateral agreement providing for up-rating. Such treaties are entered into on the basis of judgments by both parties as to their respective interests and may depend on various factors. Where an agreement is in place, the flow of funds may differ depending on the level of each country's benefits and the number of people going in each direction. It follows that there had been no discrimination and, therefore, no violation of Article 14 taken in conjunction with Article 1 of Protocol No 1.

Thus, the Court of Human Rights does not apply a concept of indirect discrimination in its case law. Instead, it considers whether the disputed ground itself is a form of direct discrimination. In respect of discrimination on such grounds, which are not sex or nationality, the Court gives ample room for a margin of appreciation for the state and therefore such cases are not successful for the applicant.

This approach is also followed in later case law. In the Efe $v$ Austria judgment ${ }^{22}$ the Court held that the applicant was not in a relevantly similar position as Austrian residents. His children lived outside Austria and the position of Austrians was that their children live in Austria, the Court considered. It did not have a feel for the indirect discrimination approach that such a rule affects mainly foreigners. In other words, the issue remains approached within the direct discrimination test. Therefore refusal of family allowances for children residing outside Austria was not contrary to Article 14 .

In Pichkur v Ukraine ${ }^{23}$ the Court followed the same approach, but the outcome was different. Benefit was refused since the applicant did not reside in Ukraine, from which country the benefit was claimed. On the basis of the direct discrimination test the Court now assumed discrimination.

It considered that in the Carson judgment the pensioners outside the UK were not in an equal position to those in the UK. It is difficult to draw any genuine comparison between the pensioners within the country and those living elsewhere, because of the range of economic and social variables which apply from country to country. This may be relevant for indexation. Thus the compared positions were not equal.

In Pichkur the person concerned had acquired a pension, and the only reason that it was not paid was that he was not living in the country. This was a comparable situation,

22 Efe v Austria App no 9134/06 9 (ECHR, 8 January 2013).

23 Pichkurv Ukraine App no 10441/06 (ECHR, 7 November 2013). 
according to the Court. The country can still mention justifications for refusing benefit, but had not done so in this case.

So the approach of the Courts is different. The Court of Human Rights applies the direct discrimination test, in this case on the ground of residence. This ground applies only in the case of persons in relevantly similar positions. Therefore the residence issue is not treated as a form of indirect discrimination on the ground of nationality (fortunate for Pichkur, who did not have a foreign nationality).

In the Court of Justice case law residence is not a general ground on which no discrimination must take place, although there are several provisions in coordination rules that prohibit residence conditions, but only for the benefits mentioned in those provisions. A residence condition in other benefit schemes has to be approached by the indirect discrimination test. ${ }^{24}$

\section{II.iii The Right to Property}

In Section II.i Article 1 of Protocol No 1 on the right to property was mentioned as a possible way to address issues of (in)direct discrimination.

The Court of Human Rights approaches this article as follows. Article 1 of Protocol No 1 does not include a right to acquire property. It places no restriction on the Contracting State's freedom to decide whether or not to have in place any form of social security scheme, or to choose the type or amount of benefits to be provided under any such scheme. If, however, a state has legislation in force which provides for the payment, as of right, of a welfare benefit, that legislation must be regarded as generating a proprietary interest falling within the ambit of Article 1 of Protocol No 1 for persons satisfying its requirements..$^{25}$

So far, invoking the right to property protection has led to little success in the area of social security. An example where there was a positive result for the applicant was the Ásmundsson judgment. This concerned a person in Iceland who had become fully disabled in 1978 as a seafarer and became entitled to disability benefit. A $200 \mathrm{~kg}$ boulder had fallen on his leg. After his accident the applicant joined a transport company, Samskip Ltd, as an office assistant, and became employed there as head of the claims department. In 1992, new legislation changed the way the applicant's disability was assessed for the purposes of his pension, so that it was to be based not on his inability to perform the same work, but work in general. Under the new rules, the applicant's disability was reassessed and his loss of capacity for work in general was found to be 25 per cent; this was below the minimum level of 35 per cent which was the accession requirement and therefore his benefit entitlement was terminated.

Of the 336 reassessments the disability pension of 104 persons was changed and 104 pensioners lost their pension altogether. Thus the measure affected the applicant in a particularly harsh manner, the Court considered, in that it totally deprived him of the disability pension he had been receiving on a regular basis for nearly 20 years and which, at the time, constituted one-third of his gross monthly income.

24 See also Chapter 3 in this volume.

25 Kopecky v Slovakia, 2004-IX § 35. 


\section{Research handbook on European social security law}

Against that background, the Court found that the applicant was made to bear an excessive and disproportionate burden which could not be justified by legitimate community interests relied upon by the authorities. It would have been otherwise had the applicant been obliged to endure a reasonable and commensurate reduction rather than the total deprivation of his entitlements.

One can have some doubts as to this approach, since it is very possible that the fact that the benefits of a small group are affected is, from a policy point of view, a justified outcome. After all, Ásmundsen could still earn a considerable income alongside his benefit. In addition, one may wonder why it is decisive, from the perspective of property protection, whether only a very small group loses all entitlement.

It seems that the Court's approach can be explained as a typical human rights perspective - 'is the outcome problematic in an individual case?' - rather than developing consistent criteria for when the infringement of benefit rights is allowed and when it is not.

This impression also appears from the Moskal judgment, ${ }^{26}$ which concerned a Polish woman who had received a Polish early retirement benefit since her son suffered from, inter alia, asthma, and therefore needed a lot of care. About 10 months later the benefit administration decided to terminate the benefit, since it now doubted whether the medical situation of the child indeed required permanent care. The Court considered that the total loss of benefit was too abrupt, and that the new benefit to which she would be entitled would be much lower. For this reason the Court decided that a fair balance between the requirements of the general interest and those of the protection of the fundamental rights of the individual were lacking and that Article 1 of the Protocol had therefore been infringed.

This means that stopping the payment of an benefit that is not needed is seen as an infringement of the right to property. However, we can hardly expect that this is the case in any instance of such payment that is not due; any general rules are lacking on this, however. Thus the Court is more focused on the individual situation than on making a more general rule on when and under which circumstances the withdrawal of a benefit is allowed.

In other cases, the Court has not held a general recourse to property protection to be successful. An example was the Valkov judgment, ${ }^{27}$ concerning the capping of pensions in Bulgaria (a pension was not paid for the amount exceeding a ceiling). As a result these persons were in some cases not paid two-thirds of their pension; the remaining pension was quite low (€81 a month in the case of Valkov). The Ásmundsen criteria might have led to the conclusion that their property rights had been infringed: the loss of pension rights was a major loss and the rule affected a small number of pensioners only. However, their claim was dismissed: they had not lost their full pension and they belonged to the 'top earners' among pensioners.

So the outcome in their individual situation - these were not really poor people was considered more relevant than a consistent application of certain criteria. After all, unlike Mr Ádmundsson, the pensioners had no other income; compared to other

26 Moskal App no 10373/05 (ECHR, 15 September 2009).

27 Valkov App nos 2033/04, 19125/04, 19475/04 (ECHR, 25 October 2011). 
pensioners they had relatively high incomes, but this was indeed relative, since the pensions were so extremely low!

Easier to understand is the argument also mentioned by the Court that the measure was a transitional measure, in view of Bulgaria's transition to a market economy.

Conclusions. The protection of property is not directly linked to discrimination on the ground of nationality, although if a benefit is withdrawn or reduced it may be indirectly concerned with nationality, e.g. because of residence. The protection of property only provides protection in case of withdrawal of benefits provided that the measure cannot objectively be justified and the applicant is made to bear an excessive and disproportionate burden which could not be justified by the legitimate community interests relied on by the authorities.

\section{THE PLACE AND APPLICABILITY OF THE NON-DISCRIMINATION RULES IN EU LAW}

\section{III.i Introduction}

In the Treaty on the Functioning of the EU (TFEU) and its predecessors, the prohibition of non-discrimination on the basis of nationality is a fundamental principle laid down in Article 18 TFEU and Article 45 TFEU.

\section{III.ii Direct Discrimination against EU Nationals}

\section{III.ii.a Workers}

Article 45 TFEU ensures the free movement of workers and non-discrimination in the area of working conditions. Restrictions are only allowed if these can be justified on the basis of public order, public safety or public health. Article 45 also prohibits indirect discrimination.

In the area of statutory social security, Regulation 883/2004 prohibits nondiscrimination on the ground of nationality. Social assistance does not fall within the scope of the regulation and the regulation is restricted to traditional forms of social security, including unemployment benefit, an old-age pension, sickness benefit, survivors' benefits, and family allowances. Advantages such as study grants and housing benefits are thus not covered.

With respect to social advantages not within the scope of Regulation 883/2004, another regulation may be relevant, i.e. Regulation 492/2011, which prohibits all discrimination on the ground of nationality for workers (with EU nationality). The objective justifications in case of discrimination are limited: public order and public health, and these have consistently been given a narrow interpretation by the Court of Justice.

For non-workers Article 18 TFEU is relevant as it reads that within the scope of application of the Treaties, and without prejudice to any special provisions contained therein, any discrimination on grounds of nationality shall be prohibited. In connection with the provision on European citizenship, Article 21 TFEU, Article 18 can be invoked by all EU citizens. 


\section{Research handbook on European social security law}

\section{III.ii.b EU citizens}

Invoking Article 18 TFEU is possible on the basis of the provisions on European citizenship, Articles 20 and 21 TFEU. Before discussing this, it is important to point out the priority order. If Article 45 TFEU is applicable, Article 21 is not applicable. This is important as the application of Articles 18 and 45 may have different outcomes.

Article 18 TFEU provides that within the scope of application of this Treaty, and without prejudice to any special provisions contained therein, any discrimination on grounds of nationality shall be prohibited.

In the Martinez Sala judgment, ${ }^{28}$ a landmark decision, the combination of these provisions led to an interesting outcome: a person who was no longer employed could invoke a non-discrimination rule, i.e. the predecessor of Article 18 (thus far, only employees and self-employed could do so), when she was refused child-raising benefit. The Court argued that Article 21 TFEU attaches to the status of a citizen of the Union the rights and duties laid down by the Treaty, including the right, laid down in Article 18 TFEU, not to suffer discrimination on grounds of nationality within the material scope of the Treaty.

Also in the Grzelczyk judgment Articles 18 and 21 TFEU (the present numbering) were relevant. ${ }^{29}$ The Court of Justice considered that discrimination solely on the ground of nationality is in principle prohibited by Article 18 TFEU.

Article 21 TFEU indeed has important effects. Whereas a Member State was previously required to assume full social responsibility and provide welfare for those who had already entered its employment market and who thus made some contribution to its economy, such financial solidarity is now in principle to be extended to all Union citizens lawfully resident on its territory. Yet it should be noted that certain limits remain. As regards assistance covering the maintenance costs of students, the Court accepted in the Bidar judgment ${ }^{30}$ that Member States are permitted to ensure that the granting of social assistance does not become an unreasonable burden upon them and that the granting of such assistance may be limited to students who have demonstrated 'a certain degree of integration'. This was further elaborated in the Förster judgment. ${ }^{31}$ Jacqueline Förster, a German national, was confronted with the Dutch rule that study finance may be granted to students who are nationals of a Member State if, prior to the application, they have been lawfully resident in the Netherlands for an uninterrupted period of at least five years. The Court investigated whether such a requirement can be justified by the objective of the host state's policy of ensuring that students who are nationals of other Member States have, to a certain degree, integrated into its society. The Court decided that this condition is appropriate for the purpose of guaranteeing that the applicant is integrated into the society of the host state.

Thus, Article 18 in conjunction with Article 21 does not remove all discrimination on the basis of nationality; instead, Member States may require a certain degree of integration by a claimant into their society before this article can be invoked. Five years is considered to be a period which is proportional.

28 Case 85/96 [1998] ECR I-2691.

29 Case 184/99 [2001] ECR I-6193.

30 Case C-209/03 [2005] ECR I-2119.

31 Case C-158/07 Jacqueline Föster [2008] ECR I-8507. 
In the Charter of Fundamental Rights of the European Union the non-discrimination principle is also mentioned (Article 21). This provision is elaborated in the provisions mentioned in this section.

Conclusions. Direct discrimination on the ground of nationality is not allowed under EU law for economically active persons apart from very limited exceptions. Also for EU citizens, protection against discrimination on the ground of nationality will apply. These rules apply to EU nationals only.

\section{III.iii Indirect Discrimination against Workers}

An example of the application of the prohibition of indirect discrimination can be seen in the Pinna case, ${ }^{32}$ where the Court decided that the coordination regulation for social security ${ }^{33}$ was not allowed to provide that persons employed in France received family benefits at the level of the state of residence. As a result, persons employed in France received for their children residing, for example, in Greece, child benefit in accordance with the Greek rules, which meant a lower benefit. The Court considered that the principle of equal treatment prohibits not only overt discrimination based on nationality, but all covert forms of discrimination which, by applying other distinguishing criteria, in fact achieve the same result.

Under EU law in case of a distinction which raises a suspicion of indirect discrimination an objective justification is possible. Consequently, indirect discrimination is not generally forbidden. Indirect discrimination occurs, in the area of nationality, in particular as a result of residence conditions. Residence conditions generally affect larger numbers of persons with a nationality other than that of the state which imposes this condition. Also the regulation itself has examples of residence conditions and these may be reconsidered. Generally under EU law residence conditions are forbidden, and objective justifications relating to costs, administrative problems, comparisons between national workers and foreign workers and population policy are not accepted.

A major case in which the Court did not decide that a discriminatory rule under the regulation was inconsistent with the Treaty concerned unemployment benefit for wholly unemployed frontier workers. Wholly unemployed frontier workers are subject to the legislation on unemployment benefits in their country of residence, even if they seek work in the country of their last employment in addition to seeking work in the state of residence. For frontier workers wishing to be available to the employment services in the state of employment, this rule is unsatisfactory, as it implies that they are deprived of the rights they acquired by virtue of the legislation of the state of employment. In the Mouthaan judgment ${ }^{34}$ the Court held that the rule was not inconsistent with the Treaty. The Court accepted (actually: it itself invented) an objective justification: since frontier workers have better opportunities on the labour market in their country of residence it was permissible to determine that their unemployment benefits are also according to the legislation of this country.

32 Case 41/84 [1986] ECR 1.

33 Article 73(2) of Regulation 1408/71.

34 Case 39/76 [1976] ECR 1901. 


\section{Research handbook on European social security law}

Conclusions. In case of indirect discrimination, objective justifications are allowed, though reasons only qualify as such if they meet the conditions set by the Court. However, such cases may imply a loss of benefit rights, and thus an infringement of the protection of property.

\section{III.iv Discrimination against Third-Country Nationals}

The provisions concerning non-discrimination in Articles 18 and 45 TFEU can be invoked by EU nationals only. For Article 45, this is the result of the fact that Article 45 is part of the section on the free movement of persons, which is one of the fundamental freedoms essential to the EU, and therefore for workers with the nationality of an EU Member State. Also the scope of Article 18 TFEU is limited to EU citizens.

As we have seen in the description of the European Court of Human Rights' case law, there are several cases where a person in an EU Member State was excluded from a particular benefit, whereas at the material time of the case recourse to EU law was not successful (eg in the case of Gaygusuz).

Let us first consider the current EU law. Also at present the nationality condition is essential for being covered by the coordination regulation for social security for migrant workers (Regulation 883/2004). This regulation contains an important nondiscrimination rule in the area of statutory social security (social assistance benefit is excluded from the material scope). Thus this rule prohibits different treatment for EU nationals (and EEA and Swiss nationals). As a result a third-country national cannot invoke this rule to combat discrimination on the ground of nationality.

This nationality condition has been severely criticised for excluding third-country nationals. A major point of discussion was whether Article 42 EC (now Article 48 TFEU) could be a suitable legal basis for an extension of the coordination regulation to third-country nationals. This issue was solved by the Court of Justice in the Khalil judgment. ${ }^{35}$ From this judgment it follows that Article 48 TFEU cannot be a legal basis for extending the personal scope to third-country nationals, since the Court decided that the scope of this article is limited to EU nationals. Only they enjoy the freedom of movement guaranteed by the Treaty.

The Court made an exception for stateless persons and political refugees, which were the appellants in this case. They could rely on the regulation, since they were mentioned in the regulation and because of the UN conventions on stateless persons and refugees this (limited) extension was allowed. The appellants applied for child benefit in Germany, which was refused to foreigners who did not have a residence entitlement or residence permit. Those involved were, among others, Kurdish and Palestinian refugees from Lebanon, who had already lived for 10 years in Germany when they were confronted with this law. However, although they were within the personal scope of the regulation, their claim was still not successful. This was because the Court referred to its case law, the Petit judgment in particular, ${ }^{36}$ in which it concluded that Article 51 EC Treaty (now Article 48 TFEU) and Regulation 1408/71 do not apply to situations which are confined within a single Member State. This is in

\footnotetext{
35 Case 95/99 [2001] ECR I-7413.
}

36 Case 153/91 [1992] ECR I-4973. 
particular the case where the situation of a worker has factors linking it solely with a non-member country and one single Member State. Consequently, the refugees and the stateless persons in this case could not rely on the rights conferred by the regulation now that they were in a situation which was confined in all respects within one Member State. This means that stateless persons and refugees can benefit from this decision only when their situation involves two Member States.

The European Commission thereby made a new proposal, this time based on Article 63(4) EC (now Article 79 TFEU). This article concerns the conditions for the admission and residence of third-country nationals to the Community. This legal basis for making a regulation was accepted by the Council and in 2003 Regulation 859/2003 was adopted. ${ }^{37}$ This regulation meant that third-county nationals can, under certain conditions specified below, invoke the non-discrimination rule. When Regulation $883 / 2004$ was adopted a new regulation on third-county nationals was necessary; after long and intensive discussions this was adopted, i.e. Regulation 1231/2010.38

Both regulations provide that the coordination regulation shall apply to nationals of third countries who are not already covered by those regulations solely on the ground of their nationality, as well as to members of their families and to their survivors, provided that they are legally resident in the territory of a Member State and are in a situation which is not confined in all respects within a single Member State. The italicised condition is of decisive importance since it means that the regulation can only be applicable if a situation concerns facts in at least two Member States (eg a worker from France who goes to work in the Netherlands). If, however, a person has come from a non-EU state and has remained in one and the same EU Member State, then the regulation is not applicable. ${ }^{39}$ Therefore the non-discrimination rule is still of limited value for third-country nationals. In other words, they can still be discriminated against without the possibility of invoking an EU non-discrimination rule.

Conclusions. For third-country nationals, invoking EU law is limited. For the coordination regulation an opening has been made, since invoking the regulation is possible if the facts of the case are not limited to one Member State. For other instruments the exclusion is still absolute.

\section{COMPARISON OF THE EU AND ECHR APPROACHES}

\section{IV.i The Prohibition of Direct Discrimination}

In the case of direct discrimination against persons with EU nationality the approach of EU law and the Convention do not differ significantly. The European Court of Human

37 [2003] OJ L 124 1. See the preparatory work in [2002] Com 59.

38 [2010] OJ L 3441.

39 An interesting question is what the position of Denmark, the UK and Ireland is in this respect. It is clear, of course, that a third-country national cannot invoke the regulation if s/he first works in Belgium and then moves to Denmark, in order to have periods of insurance aggregated. However, what about the reverse situation? If s/he moves to Belgium, can s/he have his or her Danish periods added to the Belgian ones?

Columns Design XML Ltd / Job: Pennings-Research_handbook_European_social_security_law / Division: 07_Chapter6 /Pg. Position: 17 l Date: 


\section{Research handbook on European social security law}

Rights requires that there must be 'very weighty' reasons to justify discrimination, whereas under EU law there is a specified number of exceptions to the prohibition of discrimination. We may assume that these terms will largely overlap, although the EU grounds are more specific.

Still, in terms of scope, the approach to discrimination differs considerably. This has to do, in large part, with the framework within which the discrimination terms occur. For the EU the non-discrimination rule is basically linked to free movement, i.e. initially of EU workers and the self-employed. As of 2010 this has been extended in the area of statutory social security to the free movement of persons, active or inactive, but still to EU citizens only.

Article 18 TFEU is also of use, in that it removes nationality conditions for benefits not within the scope of Regulation 883/2004, for instance for social assistance. This is relevant for those who are not workers.

In these cases there is, in the Court's case law, more room for an objective justification than in the case of the regulations. In the Förster judgment, ${ }^{40}$ the Court decided that the condition that the applicant must have a certain degree of integration into the society of the host state is acceptable as an objective justification for a residence condition. This condition must be well reasoned, adequate and proportional.

There is, as yet, no comparable European Court of Human Rights case law. Since the condition which was applicable in Förster was applied to foreigners only, it is a form of direct discrimination, and thus would require very weighty reasons had it been a case before the European Court of Human Rights. How this Court would decide the case is still not clear.

The criteria and arguments of the Court of Justice are well founded and satisfy the proportionality criterion. Still, the criterion of the degree of integration applies to foreigners only (and not to persons with the nationality of the host state); thus the distinction that is made between economically active persons and others is different from the European Court of Human Rights' case law so far. Whether these constitute 'very weighty' reasons remains to be seen.

Another distinction is between EU nationals and non-EU nationals. We have seen that gradually the scope of the non-discrimination rule has been extended to non-EU nationals, but only if the facts of the case are not restricted to one Member State (in statutory social security), or depending on whether there is an agreement. The condition that the facts must not be restricted to one Member State also applies for EU nationals, but for the latter it is much easier to satisfy this condition. It can therefore be disputed whether the criterion for third-country nationals is a very weighty reason. I will discuss this in the next section. In other areas (Article 18 TFEU) the exclusion of third-country nationals is an absolute one.

\section{IV.ii Can the ECHR Lead to Different Outcomes?}

Can cases of direct discrimination which do not fall under EU law or which are still allowed by EU law be addressed by the Convention?

40 Case C-158/07 Jacqueline Föster [2008] ECR I-8507. 
If we look again at the Gaygusuz case, it has to be noted that EU law has changed to the extent that a regulation on third-country nationals (Regulation 1231/2010) has been adopted, which did not exist at the time of the Gaygusuz decision. This regulation extends the non-discrimination provision of the coordination regulation to third-country nationals such as Mr Gaygusuz. A particular problem, however, is that this emergency assistance is probably a form of social assistance and is thus excluded from the scope of the coordination regulation.

However, and this is of more general importance, the mentioned regulation only applies if not all the facts of the case are limited to one Member State. Even if this emergency benefit is within the scope of the regulation, $\mathrm{Mr}$ Gaygusuz could not contest his exclusion from the benefit by means of the Regulation 1231/2010 either.

Also the EU citizens' provision (Article 18 TFEU) is limited to EU nationals. $\mathrm{Mr}$ Gaygusuz could not invoke this rule successfully either. Therefore, invoking the Convention is still necessary for Mr Gaygusuz if benefit is refused on the ground of nationality. ${ }^{41}$

Therefore, the very limitation of the equal treatment rules to EU nationals constitutes a form of discrimination which may be tested against the Convention. As we saw, in respect of statutory social security this discrimination has been lifted to a considerable extent, the main difference being that the situation must not be limited to one Member State.

Are there weighty reasons for this difference? The rule that the coordination regulation is only applicable if the facts of the case are not limited to one Member State was established in the Petit judgment. ${ }^{42}$ In this case an employee was confronted with conditions on the use of language to be used in legal procedures in Belgium. The Belgian law on languages to be used in legal proceedings prescribed the Dutch language in a case like this. The use of another language would make the case of the person concerned inadmissible. When Mr Petit challenged this it was considered that he had Belgian nationality and had never been employed in a state other than Belgium. The Court of Justice decided that the rules of the Treaty ensuring the free movement of workers and the coordination regulation were not applicable to activities all elements of which are restricted to the territory of a single Member State only. This criterion was also at stake in the Government of the French Community and Walloon Government $v$ Flemish Government judgment. ${ }^{43}$

In the Khalil case 44 (see Section III.iv) the Court reiterated this condition and Regulation 1231/2010 has reproduced it. This means that only if a situation concerns

41 Decision 3/80 of the Association Council will provide the same result since this decision has the same material scope as the coordination regulation. The Decision will be beneficial for other types of benefits, but for Turkish nationals only. So for other third-country nationals linked to one Member State only, the Convention provides a result which is different from EU law.

42 Case 153/91 [1992] ECR I-4973.

43 Case C-212/06 [2008] ECR I-1683. See on this judgment also H Verschueren, 'De regionalisering van de sociale zekerheid in België in het licht van het arrest van het Europese Hof van Justitie inzake de Vlaamse zorgverzekering' (2008) 2 Belgisch Tijdschrift Sociale Zekerheid 177-232; I van der Steen, 'Zuivere interne situaties: geen omwenteling, wel inperking' (2008) 11 NTER $301 \mathrm{ff}$.

44 Case 95/99 [2001] ECR I-7413. 


\section{Research handbook on European social security law}

facts in at least two Member States (eg a worker from France who goes to work in the UK) is the regulation applicable. If, however, a person has come from a non-EU state and has remained in one and the same EU Member State, then the regulation is not applicable. This limitation can also be found in the Khalil judgment, and earlier in the Petit judgment. Still, this limitation could be criticised, as, unlike these two cases, the regulation on third-country nationals is not based on Article 48 TFEU, but on Article 63(4) EC. This separate legal basis is not related to the right to free movement, which is indeed related to the economic freedoms established within the EU. Therefore the question arises why at least the facts of two Member States have to be involved.

For third-country nationals the effect of this requirement differs from that for EU nationals, such as Mr Petit in the Petit judgment, ${ }^{45}$ as the former persons are from a third country and are therefore much more likely to be discriminated against on grounds of nationality. The third-country nationals cannot, as a result of the condition that two Member States must be involved, invoke the regulation in, for instance, a case of discrimination on grounds of nationality which occurs within a Member State if they do not work, reside or stay in another Member State. One can therefore doubt whether the difference within this EU instrument constitutes a weighty reason for making a distinction. ${ }^{46}$

Regulation 1231/2010 would probably not be of help in the Poirrez case either. In respect of the father it was argued that he was not a migrant worker. Under the new formula one would say that the facts of the case did not involve two Member States. Thus neither the father nor the son could invoke the regulation.

The Polish case of Luczak v Poland would, of course, lead to a different outcome now that Poland is a member of the EU. The Court seemed to tease the Polish government by saying that it had not explained why its public policy goals in respect of the farmers' scheme suddenly lost their relevance after 2004, since the answer is obvious: Poland was no longer allowed to make this distinction towards other EU nationals after it acceded to the EU. However, this remark is still relevant to us, since it shows that EU membership itself is no longer a self-evident ground, at least for the European Court of Human Rights, for making or not making differences.

Regulation 1231/2010 is relevant only to benefits within the scope of this regulation. Discrimination occurring in areas not covered by this regulation can be combated by means of Regulation 492/2011 or Article 18 TFEU (in combination with EU citizenship). The personal scope of both instruments is limited to EU nationals. Also here one can doubt whether this is consistent with the Convention. Are there very weighty reasons to exclude third-country nationals (who are legally staying in a Member State) from invoking EU law rules? As we saw in respect of the coordination regulation, there was a great deal of doubt as to whether this regulation could be based on Article 48 . Only after the Court of Justice decided that in view of the place of the legal basis for

45 Case 153/91 [1992] ECR I-4973.

46 Some Member States can exempt themselves from the Regulation: Denmark, the UK and Ireland. We will not go into this issue too deeply here, but it is doubted whether these states can now refuse to apply the equal treatment principle if the Union is bound by the Convention. As a result the non-discrimination law will also affect their reservations to the Regulation.

Columns Design XML Ltd / Job: Pennings-Research_handbook_European_social_security_law / Division: 07_Chapter6 /Pg. Position: 20 / Date: 
the regulation in the Treaty (ie in the chapter on free movement, a freedom created for EU nationals) did it decide that third-country nationals could not be involved.

This argument need not constitute, in itself, a very weighty reason, and it is certainly not sufficient to justify any form of discrimination. Therefore we may expect that when third-country nationals wish to invoke EU rules and are refused on the basis of nationality, the Convention may provide an instrument to fight this discrimination successfully.

\section{IV.iii Residence Conditions}

There are some residence conditions that are accepted in the coordination regulation, for instance in the case of wholly unemployed frontier workers. As we have seen, the justification for this residence condition lies in the fact that frontier workers have a better position on the labour market in the country where they reside.

The Court of Human Rights does not apply a concept of indirect discrimination. Therefore it is unlikely that it will consider the coordination rule to be contrary to the prohibition of discrimination on the ground of nationality. In cases of residence conditions the Court of Human Rights compares the situation of persons claiming that they are treated differently from other persons, e.g. the position of persons whose pensions are upgraded and that of those whose pensions are not upgraded. This comparison is quite complicated and has thus far not led to positive results for the persons concerned in residence cases. It is not likely that the Court of Human Rights would come to the conclusion, in the (rare) cases where the Court of Justice has accepted residence conditions, that these would infringe Article 14 ECHR, because of the reticence of the Court of Human Rights to award the claims of appellants and also because the Court of Justice mentions elaborated grounds of justification. If such a case were to reach the Court of Human Rights, however, it would have to assess the objective justification given by the Court of Justice, and this might influence the way it constructed its argument.

The use of these objective justifications made by the Court of Justice seems to be more satisfactory in cases of indirect discrimination (in any case when residence conditions are concerned), than the use of a comparison of situations, which is performed by the European Court of Human Rights. First of all, as a general problem it is often difficult to compare situations since it is difficult to know which elements have to be taken into account. The Carson situation clearly shows these problems. Secondly, is it not because it is indirect discrimination rather than direct discrimination that situations are difficult to compare? In other words, should we not use a different instrument? This is not unimportant, since the British rules had a large negative effect on the pensions in Carson. A well-elaborated justification that there is no infringement of the discrimination rules is desirable.

Whether the accession of the EU to the ECHR will lead to changes in views by the European Court of Human Rights on the way discrimination cases have to be dealt with is uncertain at this moment in time. Given the differences in approaches such changes could be possible and would even be desirable if such effects were to occur. 


\section{Research handbook on European social security law}

\section{IV.iv Protection of Property}

Protection of property in social security is not an issue regulated by EU law as such. The protection of property is mentioned in the Charter of Fundamental Rights of the EU (Article 17), but so far it has not been interpreted as pertaining to social security.

In some cases before the Court of Justice, however, the principle of the protection of property was invoked vis-à-vis social security, and therefore it is interesting to compare the Court's approach with that of the Court of Human Rights. The Testa case ${ }^{47}$ involved the rule that an unemployed person can seek work abroad (while remaining in receipt of unemployment benefit) for three months. However, if he returns too late he loses all remaining benefit rights. Thus the EU rules deprive him of benefit rights acquired on the basis of national legislation. The effects of a late return can thus be quite harsh, depending on the duration of the benefit entitlement involved.

The Court discussed - in answer to the national court's questions - whether the disputed article (Article 69(2) of the then coordination regulation) infringed the fundamental rights guaranteed in this manner by Community law, i.e. Article 14 of the German Basic Law with regard to the protection of the right to property. Although the property protection rule was at stake, no reference was made to the ECHR.

The Court considered that the question of a possible infringement of fundamental rights by a measure of the Community institutions can only be judged in the light of Community law itself, since fundamental rights form an integral part of the general principles of the law, the observance of which it ensures. One of the fundamental rights which is accordingly protected under Community law in accordance with the constitutional concepts common to the Member States and in the light of international treaties for the protection of human rights is the right to property.

In order to determine whether Article 69(2) might infringe the fundamental rights guaranteed in this manner by Community law, consideration should first be given to the fact that the system set up by this article is an optional right, which applies only to the extent to which such an application is requested by a worker, who thereby foregoes his right of recourse to the general system. The consequences are made known to the worker.

The penalty under Article 69(2) must likewise be judged in the light of the advantage of a worker per Article 69(1), which has no equivalent in national law. Moreover, in exceptional cases the three-month period may be extended. This ensures that the application of Article 69(2) does not give rise to disproportional results. ${ }^{48}$ Therefore the Court accepted an objective justification for the radical loss of benefit rights.

The test of the Court of Human Rights would, in this case, be difficult to apply. If we apply its criterion, it can be said that there seems to be an excessive burden on a particular group (of late returners), who lose all remaining rights and who may no longer have an alternative income. Still, indeed, they have an advantage of which the

47 Testa, Maggio and Viale Cases 41/79, 121/79 and 796/79 [1980] ECR 1979.

48 Regulation 883/2004 has a novelty: the person who returns too late loses all entitlement to benefit, unless the provisions of that legislation are mover favourable. Indeed, Member States may have their own rules on the period after which benefits are lost after a late return. These are applicable if they are favourable for the person concerned. 
loss of rights, if they do not satisfy the rules, is the counterpart. Therefore, if such a case were brought before the Court of Human Rights, the question would be whether its own criterion could be usefully applied. Therefore it is interesting to see which criterion the Court would apply.

Conclusion. The approach in the case of direct discrimination against EU nationals does not seem very different. In the case of third-country nationals there is an important difference. There is also a difference in the case of situations which would constitute indirect discrimination for the Court of Justice or an infringement of property.

\section{CONCLUSION}

This chapter investigated which effects follow from the EU accession to the Convention for discrimination on the ground of nationality in the area of social advantages. In other words, are cases of discrimination on the ground of nationality, which are problematic under the Convention, allowed under EU law?

As was explained in Section I, after accession to the Convention, EU law has to be interpreted so that it is consistent with the Convention, and therefore the comparison is useful to identify the differences.

From the present study it appears that the accession of the EU to the Convention will probably not have effects in all areas discussed here. This was to be expected, first since human rights have already played a role for a considerable time in Community law, and second because otherwise the EU would not have decided to accede to the Convention.

The main differences seem to lie, in the area of the prohibition of discrimination on the ground of nationality, in the treatment of third-country nationals. They are still treated differently from EU nationals in several respects in EU law. A difference in treatment on the ground of EU nationality cannot be found in the case law of the European Court of Human Rights. The Moustaquim judgment does not support such a difference, as was explained in Section II.ii.a.

This may lead to decisions in which the European Court of Human Rights decides that EU law, e.g. the exclusion of non-EU nationals from the coordination regulation, from Regulation 492/11 or from the application of Article 18 TFEU, has to be well reasoned. These grounds have to be 'very weighty', and it is possible that this criterion cannot be satisfied, since economic reasons - used within the EU context - are difficult to reconcile with the human rights approach of the European Court of Human Rights. Also in the cases before the Court of Human Rights discussed in Section II.ii. economic arguments were put forward by the state and it appeared that these were not accepted. Is it not likely that it will make a difference when an international organisation uses an economic argument.

Also cases on residence conditions and the loss of benefit rights which were allowed by EU law can be brought before the Court of Human Rights.

From the study it also appears that the courts use different types of reasoning. Since the Court of Justice's case law on indirect discrimination is quite strict, and that of the Court of Human Rights on situations that could amount to indirect discrimination is not so strict, we cannot expect many cases here. 


\section{Research handbook on European social security law}

In case of an infringement of property rights, the Court of Justice sometimes accepts such infringements. It is not clear whether the criteria of the Court of Human Rights would lead to the same outcome as those of the Court of Justice, since the Court of Human Rights uses different criteria. In any case, it seems that the Court has to change its reasoning if it wishes to accept the outcome of the case law of the Court of Justice. Thus the case law of one international court may influence the other after the accession of the EU to the Convention.

In this respect it is interesting that the Court of Human Rights has been criticised for its ad hoc approach to cases on discrimination. Mel Cousins ${ }^{49}$ has called the case law 'advocacy of palm tree justice' in cases concerning social security as a property right. By palm tree justice he means a pragmatic approach to justice that is entirely discretionary and transcends legal rights or precedent, enabling the Court to make such an order as it thinks fair and just in the circumstances of the case.

Indeed, also in the preceding sections the lack of consistent rules has been pointed to. Closer contacts between the courts and the need to take the EU dimension and case law into account may force the European Court of Human Rights to develop a clearer framework for the application of its criteria. The outcome is not easy to predict, but it may lead to interesting improvements for the EU, which has to mention new justifications for some forms of discrimination, and the Court of Human Rights, which has to take the reasoning of the Court of Justice into account and is thus challenged to systematise its reasoning.

\section{BIBLIOGRAPHY}

Besselink, L (2009), 'The EU and the European Convention of Human Rights after Lisbon: From "Bosphorus" Sovereign Immunity to Full Scrutiny?' in A Sabitha (ed), State Immunity: A Politico-Legal Study, Hyderabad: The Icfai University Press; SSRN, http://ssrn.com/abstract=1132788 or http://dx. doi.org/10.2139/ssrn.1132788.

Cousins, M (2008), The European Convention on Human Rights and Social Security Law, Antwerp: Intersentia.

Cousins, M (2009), 'The European Convention on Human Rights, Non-Discrimination and Social Security: Great Scope, Little Depth?', Journal of Social Security Law $16118 \mathrm{ff}$.

Cousins, M (2012), 'Overview of Recent Cases before the European Court of Human Rights and the European Court of Justice (January-March 2012)', EJSS 124.

Jacqué, JP (2011), 'The Accession of the European Union to the European Convention on Human Rights and Fundamental Freedoms', CMLR 995 ff.

Lock, T (2011), 'Walking on a Tightrope: The Draft ECHR Accession Agreement and the Autonomy of the EU Legal Order', CMLR 1026 ff.

Pennings, F (1999), 'The Potential Consequences of the Gaygusuz Judgment', EJSS 181.

Pennings, F (2013), 'Non-Discrimination on the Ground of Nationality in Social Security: What are the Consequences of the Accession of the EU to the ECHR?' Utrecht Law Review 9(1).

Van den Bogaerd, S (ed.) (1997), Social Security, Non-discrimination and Property, Antwerp: Maklu.

Van der Steen, I (2008), 'Zuivere interne situaties: geen omwenteling, wel inperking' NTER $11301 \mathrm{ff}$.

Verschueren, H (1997), 'EC Social Security Coordination Excluding Third-Country Nationals: Still in Line with Fundamental Rights after the Gaygusuz Judgement', CMLR 991.

49 M Cousins, 'Overview of Recent Cases before the European Court of Human Rights and the European Court of Justice (January-March 2012)’ [2012] EJSS 124.

Columns Design XML Ltd / Job: Pennings-Research_handbook_European_social_security_law / Division: 07_Chapter6 /Pg. Position: 24 / Date: 
JOBNAME: Pennings PAGE: 25 SESS: 3 OUTPUT: Thu Aug 20 09:38:05 2015

The approaches of the ECJ and ECHR 145

Verschueren, H (2008), 'De regionalisering van de sociale zekerheid in België in het licht van het arrest van het Europese Hof van Justitie inzake de Vlaamse zorgverzekering', Belgisch Tijdschrift Sociale Zekerheid 2 177-232.

Columns Design XML Ltd / Job: Pennings-Research_handbook_European_social_security_law / Division: 07_Chapter6 /Pg. Position: 25 / Date: 
JOBNAME: Pennings PAGE: 26 SESS: 3 OUTPUT: Thu Aug 20 09:38:05 2015

- 